\title{
Rock And Roll Suicide: Selvmordet i rockehistorien
}

Ved G eir Rakvaag

\author{
You're too old to lose it, \\ too young to choose it \\ And the clocks wait \\ so patiently on your song \\ You walk past a cafe \\ but you don't eat \\ when you've lived too long \\ Oh, no, no, no, \\ you're a rock ' $n$ ' roll suicide.
}

I sangen «R ock A nd Roll Suicide» fra 1972 bruker kanskje David Bowie selvmordet som en metafor for det som så ut som rockens endelikt. Rocken har imidlertid overlevd, og selvmordstanker dukker opp i musikken med ujevne mellomrom - både som lite gjennomtenkt sjokkeffekt, og som et uttrykk for mer fortvilte tanker som preger mange sangtekster i dag. $\mathrm{N}$ ettstedet allmusic.com lister opp 109 sanger med tittelen «Suicide», og 220 til med suicide som første ord $\mathrm{i}$ tittelen. $\mathrm{Og}$ dette er bare noen av sangene som omhandler temaet på en eller annen måte.

\section{Tung rock, tunge tanker}

En rekke rockegrupper har selvmord som en del av navnet: Suicide, Suicide Commandos, Suicide Kings, Suicidal Tendencies - denne lista er også lang. $\mathrm{G}$ itaristen i den finske gruppa $\mathrm{H}$ anoi Rocks kalte seg $\mathrm{N}$ asty Suicide for et internasjonalt marked.

De fleste av disse gruppene hører til i tungrocken, der selvmordsbegreper også dukker opp i tekstene - ofte som en ren sjokkeffekt sammen med andre tanker om død og evig pine. Det er også innen tungrocken vi har hatt de mest omdiskuterte tilfellene av sanger som skal ha fătt unge mennesker til å ta sine liv. Både 0 zzy 0 sborne og gruppa Judas Priest var på 80-tallet i retten for å forsvare seg for anklager fra foreldre som mente artistene forårsaket deres barns selvmord. B egge ble frikjent.

0 zzy 0 sbourne var gjennom tre forskjellige rettssaker for sangen «Suicide Solution» - som han selv hevder omhandler hans kollega Bon Scott fra A C/DC, som drakk seg i hjel i 1980:

\begin{abstract}
W ine is fine but whiskey's quicker Suicide is slow with liquor Take a bottle drown your sorrows Then it flood away tomorrows
\end{abstract}

Judas Priest ble saksøkt etter at to tenåringer skjøt seg selv, angivelig etter å ha hørt på sangen «Beyond The Realms Of Death». Det er vanskeligå finne klare oppfordringer til selvmord i teksten om en mann som har trukket seg helt inn i seg selv.
Withdrawn he'd sit there
Stare blank into space
No sign of life
Did flicker on his face
U ntil one day he smiled
It seemed as though with pride
The wind kissed him
Goodbye - and then he died.

I stedet ble musikkens suggestive rytmiske karakter og mer kryptiske beskyldninger om skjulte meldinger i lydbildet en del av anklagene.

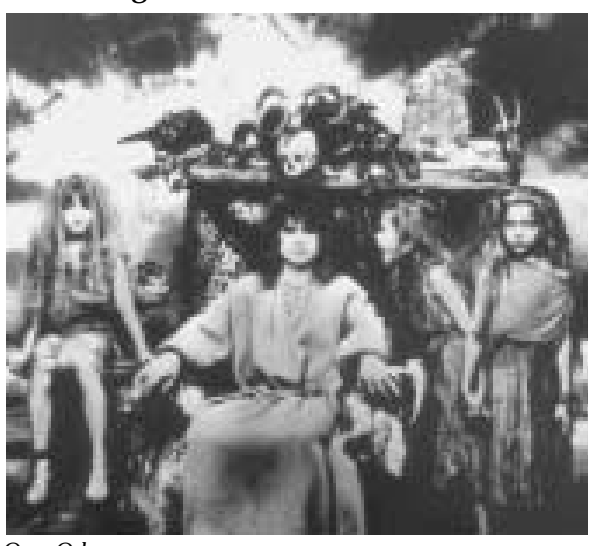
0 zzy 0 sborne

Sakene mot Judas Priest og 0 zzy 0 sborne føyer seg inn i et mønster der artister som $M$ arilyn $M$ anson og Eminem de sisteårene har fătt skylden for konkrete voldshandlinger i USA. Selv hevder M anson, og mange andre med ham at de er syndebukker for problemer i familien og i samfunnet generelt. D et kan også sies at mange leser litt for mye inn i disse tekstene, i etterpåklokskapens lys. En 17-åring som kastet seg foran et tog i Storbritannia tidligere i år, etterlot seg en transkripsjon av Eminems «Rock Bottom» - en låt som handler om å være blakk og nedfor og lei av det meste.

that's rock bottom

when this life makes you

mad enough to kill,

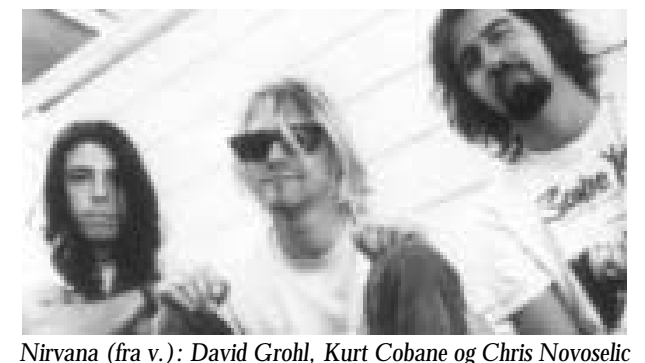

sier den omdiskuterte rapperen, og det er vel mer dagligdags frustrert sjargong enn ondsinnet propaganda. Det er ingen grunn til å ta Britney Spears vel dig alvorlig når hun synger «this loneliness is killing me» $\mathrm{i}$ «H it M e Baby O ne M ore Time».

A t mange tungrocksanger handler om selvmord, er likevel utvilsomt. Som M etallica, det aller største «heavy metal»bandet, i sin første ballade, «Fade to Black»:
N o one but me can save myself,
but it's too late
N ow I can't think,
think why I should even try
Yesterday seems as though
it never existed
Death greets me warm,
now I will just say good-bye.

James $\mathrm{H}$ etfield, gitarist og vokalist i gruppa, bekrefter dette til magasinet $\mathrm{G}$ uitar W orld, men hevder samtidig at han har fått veldig mange reaksjoner fra folk som føler at de har fått det bedre etter å ha hørt denne sangen.

Det ligger i hardrockens musikalske natur at den kan være et utløp for noen av menneskets mest desperate tanker. Den mest aggressive delen av rocken fortsetter å gi utløp for disse følelsene som i «A dam's Song» av Blink 182, en av de siste årenes største nye stjerner:

I couldn't wait till I got home

To pass the time in my room alone I never thought I'd die alone

A nother six months I'll be unknown Give all my things to all my friends You'll never set foot in my room again.

\section{Stjerner og selvmord}

Rockens historie inneholder ikke så mange tilfeller av vel dig kjente artister som har tatt sitt eget liv. Desto flere har $ø$ delagt seg selv ved langvarig destruktiv livsførsel. Det vakte liten oppmerksomhet da sangeren N ick Drake tok en overdose beroligende piller i 1972, men senere har stadig flere oppdaget de tre platene han etterlot seg, og D rakes melankolske tekster har et langt større publikum i dag enn da han levde. $N$ oen av disse sangene kan høres ut som rop om hjelp, men de inneholder ingen konkrete selvmordstanker. 


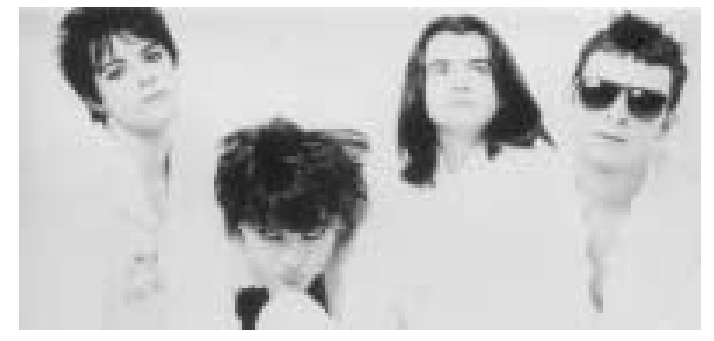

$M$ anic Street Preachers (fra v.):

Richie E dwards, N icky W ire,

Sean M oore og James D ean B radfield

I 1980 hengte sangeren Ian C urtis fra Joy Division seg på loftet hjemme hos seg selv. Den engelske gruppa sto på terskelen til et større gjennombrudd. Platene som fulgte, singelen «Love Will Tear U sA part» og albumet «C loser» ble, som disse titlene alene antyder, viktige symboler for store deler av en ungdomsgenerasjon som oppfattet inngangen til 80-tallet som en tung tid. D et går ei linje fra Joy Division fram til $\mathrm{N}$ irvana og Kurt Cobains mye omtalte selvmord i 1994.

Kurt Cobain holdt rockemytene i live ved å etterlate seg et brev der han avsluttet med å sitere $\mathrm{N}$ eil Youngs berømte linjer «It's better to burn out than to fade away». Cobain hadde allerede laget sangen «l $\mathrm{H}$ ate $M$ yself $A$ nd W ant To Die», og ble rockens største martyr siden Jimi H endrix og Jim M orrison, som begge hadde vært døde i nærmere 25 år.

I 1995 forsvant Richie Edwards sporløst. $\mathrm{H}$ an var gitaristen i den populære britiske gruppa M anic Street Preachers. H an etterlot seg albumet «The H oly Bible» med sanger som «A rchives Of Pain», «Die In The Summertime» og «T he Intense H umming of Evil». G ruppas i utgangspunktet uhøytidelige versjon av «T heme From M.A.S.H .», «Suicide Is Painless», fikk kanskje også ny mening.

'C ause suicide is painless

it brings on many changes

and I can take or leave it if I please.

....and you can do the same thing if

you please.

Richie Edwards' skjebne er fortsatt ukjent, men $\mathrm{M}$ anic Street Preachers kom tilbake mer populære en noen gang før. Tittelsangen på al bumet som fulgte høres ut som en bønn om å leve videre.

\section{Freed from the memory \\ Escape from our history, history \\ A nd I just hope that you \\ can forgive us \\ But everything must go.}

A lle selvmordsforsøkene får vi ikke vite om, men de er sannsynligvis tall rike. M el B Fra Spice G irls forteller i sin nye selvbiografi om et sel vmordsforsøk i tenårene, etter langvarig mobbing. David $\mathrm{G}$ ahan fra den svært populære gruppa D epeche M ode ble reddet i siste liten i 1995, etter mange års rusmisbruk. - Jeg ble forbanna da Kurt Cobain begikk selvmord. Jeg følte at han hadde stjålet min idé, sa han til magasinet U ncut i vår, kanskje i et forsøk på å avdramatisere hendelsen .

Da er det mer alvor i Elton Johns «Someone Saved M y Life Tonight» fra 1974,

ført i pennen av hanstekstforfatter Bernie Taupin, som en sen kveld på 60-tallet, før det store gjennombruddet, fant superstjernen bevisstløs på kjøkkengulvet med gassen skrudd på:

\section{It's four o'clock in the morning}

Damn it listen to me good

I'm sleeping with myself tonight

Saved in time, thank G od

my music's still alive.

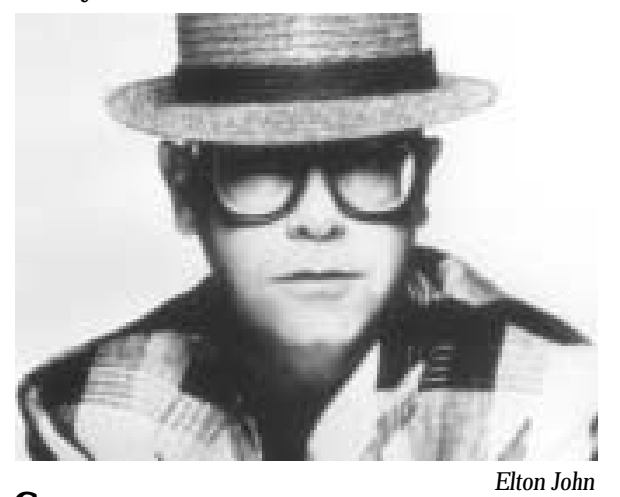

\section{Sanger om regn}

- Kurt C obain hadde motet til å gjøre det. Jeg beundrer folk som er selvdestruktive, sa sangeren M orrissey fra gruppa The Smiths til magasinet Q i 1995. Selv hadde han på 80-tallet fortsatt Joy Divisions dveling ved det depressive, og blitt forbilde for en ny generasjon sangere og grupper som har gjort tungsinnet til et av rockens fremste særtrekk de siste årene. The Smiths var på grensen til det parodiske med sanger som «H eaven Knows I'm M iserable N ow», «Last N ight I Dreamt That Somebody Loved M e» og «T he Boy W ith The Thorn In H is Side», men med deres godt utviklede sans for mollstemte melodier ble de et av de mest innflytelsesrike rockebandene på 80-tallet. D et er ikke tilfeldig at det er en plakat av M orrissey som henger på veggen på jenterommet $\mathrm{i}$ filmen «Fucking Â mål». O gså utenfor den allerede omtalte tungrocken har vi sett en tendens til at en bemerkelsesverdig lang rekke av de mest populære nye gruppene de siste årene lager sanger som er svært mørke og dystre. Dette er en del av rocken som gjerne blir hørt på av mennesker som er spesielt interesserte i musikk, og ofte hører veldig godt etter hva sangene prøver å formidle. Den nye plata til den britiske gruppa Tindersticks begynner med sangen «Dying Slowly», som forteller om et sørgelig meningsløst liv med konklusjonen «It seems dying slowly is better than shooting mysel f». Dette er nesten optimisme i denne sammenhengen.

Travis, det mest populære nye britiske bandet de siste årene, får folk til å hoppe opp og ned på konserter mens de synger «W hy Does It A Iways Rain On M e». Innholdet fortoner seg nok noe annerledes hjemme på hybelen. $N$ år disse artistene blir spurt om hvorfor sangene deres må være så nedtrykte, svarer de som oftest at det er disse stemningene som inspirerer til låtskriving. De fleste tror også at mange finner trøst i slike sanger, og at sangene som konsekvens har en oppløftende snarere enn en depressiv virkning. Som hovedpersonen i N ick Hornbys «High Fidelity», en av de siste årenes største romansuksesser, spør seg selv: $\mathrm{H} ø$ rer han på mistrøstig musikk fordi han er nedfor, eller er han nedfor fordi han hører på mistrøstig musikk?

Britiske Coldplay er også inne på mange tunge tanker $\mathrm{i}$ «Parachutes», en av de mest sol gte rockeplatene i $\mathrm{N}$ orge det siste året. De avslutter imidlertid med et lite håp:

When you thought it was over,

You could feel it all around,

Everybody's out to get you,

Don't you let it drag you down.

Slik er nemlig også rocken en hyllest til livet - aller best formul ert av R.E.M . i den etter hvert veldig kjente «Everybody H urts»:

W hen the day is long and the night, the night is yours alone,

when you're sure you've had enough of this life, well hang on.

Don't let yourself go

everybody crie

and everybody hurts sometimes.

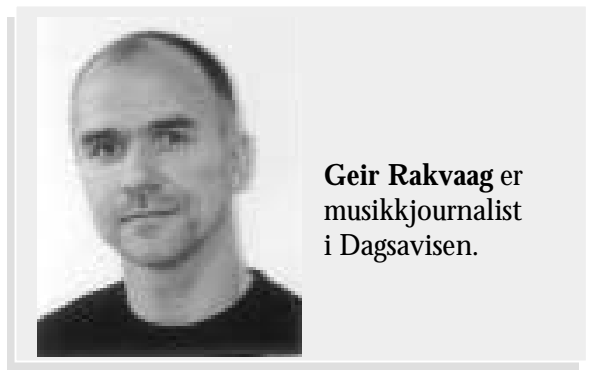

